\title{
Speed strategy of public administration services in fulfilling the basic rights of citizens in rural areas in Indonesia
}

\author{
Sry Rosita*; Andang Fazri; Ratih Kusumastuti; Syahmardi Yacob
}

Department of Management, Faculty of Economics and Business, Universitas Jambi, Indonesia

*To whom correspondence should be addressed. Email: sry_rosita@unja.ac.id

\begin{abstract}
The main purpose of this research is to examine the speed strategy of public administration services in fulfilling the basic rights of citizens in rural areas in Indonesia. The method in this research is descriptive type with quantitative approach and use explanatory survey. The target of the research was villagers in four districts in Jambi Province. The instrument used to collect the data is by using a structured questionnaire given to the sample respondents. The statistical tool to examine the hypotehsis is by using Partial Least Square (PLS) method with smart-PLS as the software. The study found that the speed strategy of public administration services has a positive and significant influence on fulfilling the basic rights of citizens in rural areas. However, these positive and significant effect towards fulfilling the basic rights of citizens are mediated by public administration services. These suggest that the role of public administration services in rural areas should be transparent, accountable, and it needs to accommodate public participants and public right equally.
\end{abstract}

Keywords: Basic rights, Public administration, Rural areas, Speed strategy

JEL Classifications: H83, O18

\section{INTRODUCTION}

Public service is one of the fundamental aspects at the national, provincial and rural levels of government. Public services are not only discussed bureaucratic management but discusses fulfillment the needs of the community. Public services administrations to more open, transparant, accountable, cost effective and responsive (Bala, 2017). One form of public service provided is public administration services. Public administration services related to community needs related to ownership of official documents as proof of authenticity and validity from identity as a citizen and obtain legal recognition (Mosso, Singkoh \& Sumampow, 2018).

The research results from Angkat, Kadir \& Isnaini (2017) show that public administration services are well implemented that are according to the requirements and applicable procedures so that the community feels unbearable and services are provided free of charge. Saputra, Afifuddin \& Widodo (2019) the community is satisfied with administrative services provided because the service officer able to handle complaints from the public, reliable in terms of time and the accuracy of the service process, communication between service officers and the community during administration files, the community feels comfortable when handling administrative files. People who are taking care of administrative files served by heart if there are people who experience difficulties in filing, there are criticisms and complaints that need to be conveyed, then 
the service officer willing to accept the input as introspection to give better service. The research conducted by Brinkerhoff, Wetterberg, Wibbels (2017) which states that citizen satisfaction with public administration services influenced by the distance of access to services.

However different results are shown from the research conducted by UGM Center for Population and Policy Studies with the Yogyakarta City Government, States that the community as users of public services does not feel satisfaction from the services provided, this is triggered by reasons related to regulations and service systems determined unilaterally by the related bureaucracy regardless of community needs, the bureaucracy does not try to understand the difficulties faced society and has not been able to accommodate community aspirations, this research is in line with the research conducted by Rukayat (2017) which states that the public services provided are still unsatisfactory because if viewed in terms of facilities still less attention, so that people feel they are not being served well. Unavailability of information facilities make service slower so that in taking care of administrative files people have to wait in line for their turn. In fact there are still many bureaucracies that provide public services can not satisfy the community. So that the public services provided can run well and have reliable quality and able to create community satisfaction, a service improvement strategy is needed. Strategies for improving public services are needed in government agencies, because of the service improvement strategy then government agencies are able to fulfill the basic rights of every community.

Fadillah \& Sujianto (2018) research show that the strategy used for improve and accelerate public services with use technology strategies, innovation strategies, and operating strategies with results there is a service system and information sources obtained through electronic and non electronic media, can do licensing online, the announcement of service, there is a strategic plan from the organization, the community can provide complaints online, conduct a community satisfaction survey by online so that it can be ascertained that the community has obtained quality services in accordance with the principle of public service that is; fast, efficient, responsive, integrity, and accountable.

Public administration services carried out should be improved so that people can easily access all needs related to administrative matters. Improve the quality of administrative services carried out by making a special strategy so that can achieve goals effectively. The strategy to improve and speed up administrative services will be able to improve the quality of services provided so that it can fulfill the rights of the community as citizens. Citizens' rights are everything that is obtained by the community and one of the citizens' rights is to obtain public services. The services provided to the community are still not effective so the right of citizens to obtaining quality services has not been fulfilled, so a speed service administration strategy is needed in order to fulfill the basic rights of citizens.

Implicitly, the variable speed strategy, public administration service and fulfillment of basic rights of citizens are very interesting to be examined and studied further. This research aims to examine: 1) Speed strategy with fulfilling the basic rights of citizens in rural areas; 2) The speed strategy of public administration services in fulfilling the basic rights of citizens in rural areas.

\section{THEORETICAL FRAMEWORK}

Strategy is a tool that will be used together to achieve the desired goals. The strategy shows the form of activities that will be carried out by the organization as an effort to achieve the set goals and objectives (David, 2011). Rangkuti (2013) defines strategy as a 
priority effort that must be carried out by the organization with expectations able to reach all destinations which is in accordance with the organization's mission. Strategy simplifies the organization to achieve a set of goals and objectives. Efforts to achieve organizational goals done by designing effective strategies especially the strategy to improve accelerate public services, using strategy in carrying out public services it will be able to and realize community satisfaction and able to improve the quality of public services.

There are several strategies that can be done to improve public services, the strategy consists of (Ibrahim, 2008):

1. Self-esteem that is related to public services provided. Agencies must place officers or service officials who has the skills and qualified expertise in the field, provide services that can reach all levels of society and guided by the principle of success that is seeing success for tomorrow not only today.

2. Meet expectations that is provide the best service to the community by making adjustments for service standards that have been set in order to be able to keep up with the environment

3. Settling and rediscovery of things that is service officer having duties include accepting criticism, suggestions, and complaints from the public. The agency will try to make improvements, if old service standards cannot improve service quality.

4. Outlook that is agencies will try to continue to provide services in accordance with future demands by using various technologies which can support improvement and accelerating the quality of public services making it easier for the public to access it and become more effective and efficient.

5. Continuous improvement that is in improving public services, then the agency must be able to adjust it with environmental changes. Agencies must create a conducive atmosphere in a way provide excellent service to the community responsively.

6. Attention that is agencies must pay attention what things are needed by the community especially those relating to public services, must be able to provide service which can make people satisfied, must use the right benchmarks in answering community needs in order to be able to comply with public service standards.

7. Empowerment that is one effort in making improvements and acceleration of service by improving the performance of service officers. Service personnel should be provided education and training in order to better understand tasks as a service provider and improve skills in mastering information technology. In addition, awarding can also improve the performance of service personnel so that it can better serve the community.

According to Government Regulations Republic of Indonesia Number 96 of 2012, public service is an activity or series of activities in order to fulfill service needs in accordance with the laws and regulations for every citizen and resident for goods or services or administrative services organized by public service providers. According to Hardiansyah (2011) public service refers to giving for services both done by the government and the private sector on behalf of the government or private sector towards the community either by making a payment or not with the intention of to fulfill what is needed or which is in the interests of the community.

Public administration offers quality services, then a strategy is needed increase activities in public administration. The results of the study Kerlinováa, Tomáškováb (2014) show that public administration has obstacles in the development and implementation of strategies. Sinambela (2012) states that excellent quality of public services can be shown through several aspects, which consist of:

1. Transparency that is adhering to the principle of openness. In providing a service to the community should have an open nature disseminate information so as to obtain 
convenience to access services needed by the community, and provide services adequately so that the community is able to understand the service.

2. Accountability that is shows the level of accountability. Services provided can be justified in accordance with the provisions of the applicable legislation.

3. Conditional that is indicates that the service provided has been in accordance with its capacity service provider and recipient who are guided by the principle of effectiveness and efficiency.

4. Participatory that is indicates that the service provided impact the community to participate in making public services successful by focusing on the aspirations conveyed, the need and expectations of the community.

5. Equal rights that are all people who enjoy service will get the same handling without exception. No community can get discriminatory action which distinguishes ethnicity, religion, race, gender, class, social status, and so on.

6. Balance of rights and obligations that is service that always prioritizes justice that is considering aspects of justice for the giver and recipient of the service.

According to UNDP (2015) public services require a fundamental change in mindset on the part of public officials, where reform is directed at changing values and behavior and increasing administrative capacity, centered on efforts to deepen motivation and instill an ethos of public service. Based on Government Regulation of the Republic of Indonesia Number 96 of 2012 the administration of public servants must be based on principles;

1. Public interest involving the interests of many people but does not require a certain burden. Public interest or mutual interests must take precedence from individual interests and other interests. But still pay attention important proportion and still respect the interests of others.

2. Legal certainty in carrying out public services, automatically related to legal certainty because the law is one of the cornerstones of implementing public services which is carried out in accordance with the applicable legal rules. In addition, the behavior between the giver and the recipient of the service is bound by the law.

3. The equal rights in providing services do not discriminate.

4. The balance of rights and obligations between service providers and service recipients must meet their rights and obligations.

5. Professionalism is a skill and ability the most prominent in one particular field.

6. Participatory in the implementation of public services by paying attention to needs and expectations and aspirations of the community.

7. Equation handling or non-discriminatory handling obtained in carrying out public services is the same without looking at social strata.

8. Openness all information regarding public services delivered transparently so that it is more easily understood by the community.

9. Accountability of public services provided must be legally accountable.

10. Facilities and special handling for groups, everyone gets the same service and there is no handling which is specific to certain groups.

11. Vulnerable because it's very easily carried away and affected by things that will make people distrust.

12. Timeliness the implementation of public services must be completed according to the predetermined target by service providers.

13. Speed, convenience and affordability of facilities and infrastructure adequate so that services can be affordable by all levels of society and more facilitated with the presence of information technology. 
According to Munhurrun, Bhiwajee Naidoo (2010) there are 5 dimensions of service quality in the public service, are: 1) Tangibles; 2) Reliability; 3) Responsiveness; 4) Assurance; and 5) Empathy. In line with research Hardiyansyah (2011) there are 5 dimensions of the quality of public services, that is:

1. Physical evidence that is the government's ability to demonstrate its existence to the community. Appearance and ability of facilities and infrastructure physical government and the state of the surrounding environment is proof of the service provided by service providers that include physical facilities (buildings, warehouses, etc), equipment and equipment used (technology), and the appearance of its employees.

2. Reliability that is the government's ability to provide services according to the promised accurately and reliably. Performance must be in accordance with community expectations which means timeliness, the same service, for all customers without mistakes, a sympathetic attitude, and with high accuracy.

3. Responsiveness that is the ability to help and provide services that are fast (responsive) and appropriate to the community, with clear information. Do not let the public wait without a clear reason cause negative perceptions in service.

4. Guarantee and certainty that is knowledge, courtesy, and ability of government employees to foster community trust in the government. Consists of several components including communication, credibility, security, competence, and courtesy.

5. Empaty that is give sincere attention and individual or personal given to the community by trying to understand people's desires. Where the government is expected to have understanding and knowledge of the interests of society, understanding community needs specifically, and have a comfortable operating time for the community.

Law Number 25 of 2009, states that service standards are the benchmark used as guidelines for the implementation of services and references for evaluating service quality as the obligation and promise of the organizer to the community in the framework of quality, fast, easy, affordable and measurable services. One form of public service system is integrated service. Based on Government Regulation of the Republic of Indonesia Number 96 of 2012, integrated service system is one management unit in service delivery implemented in one place and controlled by a management control system to simplify, accelerate, and reduce costs. Integrated service systems are very important to run because they have many goals and benefits that is; 1) Providing legal protection and certainty to the community, 2) Bringing service closer to the community, 3) Shortening the service process, 4) Realizing a fast, easy, cheap, transparent, sure, and affordable service process, 5) Provide wider access to the community to obtain services. Integrated service system can be done based on the principle of integration, economics, coordination, delegation or delegation of authority, accountability, and accessibility.

Scope of public services consists of three activities which includes service of public goods, public services, and public administration services. The following is an explanation in more detail:

1. Service of public goods covering several activities that is; a) Procurement and distribution of public goods carried out by government agencies part or all of the funds sourced from the regional income and expenditure budget, b) Procurement and distribution of public goods carried out by a business entity the capital of its establishment partially or wholly sourced from state wealth and or regional assets separated, c) Procurement and distribution of public goods whose funding is not sourced from the regional income and expenditure budget or business entity whose 
capital is established partially or wholly sourced from regional assets separated, but its availability is a state mission stipulated in legislation.

2. Public services include several activities that is; a) Provision of public services by government agencies part or all of the funds sourced from the state's income and expenditure budget and or regional income and expenditure budgets, b) Public service providers by a business entity the capital of its establishment partially or wholly sourced from state wealth and or regional assets separated, c) Public service providers the financing not sourced from the state revenue and expenditure budget or regional income and expenditure budget or business entity whose capital is established partially or wholly sourced from state wealth and or regional wealth separated, but its availability is a state mission stipulated in the laws and regulations.

3. Public administration services covering several activities that is; a) Government administrative actions which is required by the state and regulated in laws and regulations in order to realize protection personal, family, honor, dignity and property of citizens, b) Administrative actions by non-government agencies which is required by the state and regulated in legislation and applied according to the agreement with service recipients.

According to the Republic of Indonesia Government Regulation Number 96 of 2012, administrative service is services organized by the organizer and produce various forms of official documents needed by the community. Lack of good data about governance in rural areas, Jairo, Nguyen, Tran and Phung (2015) in their research measured the quality of governance by using the public administration with 6 dimensions, are: 1) Participation at local levels; 2) Transparency of information; 3) Vertical accountability; 4) Control of corruption; 5) Public administrative procedures; and 6) Public service delivery.

According to Laws and Regulations Number 96 of 2012, public administrative services carried out by government agencies can be held in two forms, that is;

1. Public administration services in the form of licensing, namely: a) a. Building Construction Permit; b) Trading Business License; c) Other permissions; d) Approval letter

2. Public administration services in the form of non-licensing, namely: a) Identity Card;

b) Taxpayer Identification Number; c) Vehicle Ownership Proof; d) Land certificate

Administrative Services is a service carried out by a particular unit by covering activities recording and data collection, researching, making a decision, and documented and implementing various activities related to comprehensive administration which will eventually produce products in the form of documents, such as an annotated document, permission, and recommendations and so on. Public administration services can be in the form of providing services for making ID cards, loading family cards, domicile information, making land documents, recommendation for business place permits, legalizing, moving letters, making birth certificates (Pasolong, 2014). Public administration services will produce various types of official products which is for the whole community.

Administrative processes according to Chatzoglou, Chatzoudes, Vraimaki \& Diamantidis (2013) such as passports, visas, driver's licenses, military status certificates, birth certificates, marriages status certificates, duplicate criminal records, public transportation permits, applications for seasonal unemployment benefits, passenger vehicles, various procedures regarding public financial services, etc. through a citizen service center (CSC) citizens can make requests about the process and staff fill out applications through electronic applications thus saving a lot of time. Citizen service 
centers can reduce the level of government bureaucracy and increase the overall efficiency of the public sector

Citizens are one element of the formation of a country. Citizens consist of people who occupy an area and have relations with the state. Every individual who has settled in a country, will become citizens and will have rights and obligations as citizens. Rights are things that will be obtained and obligations are things that must be done. Citizen rights are things that are accepted by citizens after carrying out all obligations as citizens while the obligations of citizens are all things that must be carried out by citizens in order to obtain rights.

One of the rights owned by citizens is the right to obtain public services. Based on Law Number 25 of 2009, citizens' rights in public service, consisting of: 1) Know the contents of the truth of service standards; 2) Oversee the implementation of service standards; 3) Get responses to complaints submitted; 4) Obtain advocacy, protection and / or fulfillment of services; 5) Notify the organizer of the leader to improve service if the service provided is not in accordance with the standard of service; 6) Notify the executor to improve service if the service provided is not in accordance with the standard of service; 7) Complaining with implementers, who make service standard deviations and or not improve services to organizers and ombudsmen; 8) Complaining about the implementation of a service standard deviation and / or does not improve service to the organizer of the organizer and the ombudsman; 9) Get quality service in accordance with expectations and service goals.

Based on previous research regarding speed strategies, public administration services, and fulfillment of basic rights of citizens which has not been conclusive because of the limitations of empirical research. Therefore, this study estimates that the service speed strategy is able to fulfill the basic rights of citizens through public administration services. So the scheme of the basic research framework used in this research can be presented in the following figure:

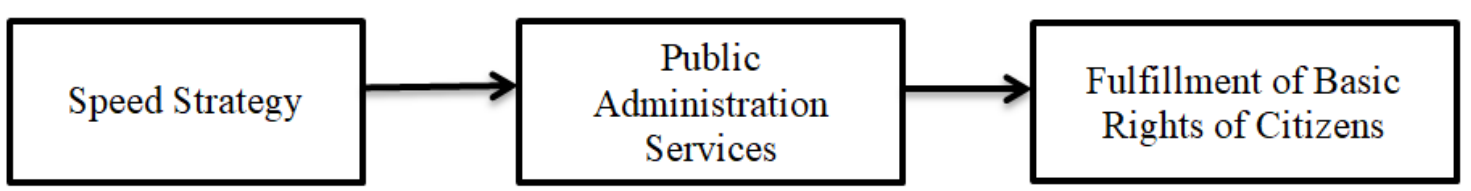

Figure 1. Research framework model

The model used in this research will be formulated into two models. Direct influence model relating to the construct of speed strategy and the consequences of consequences towards fulfilling the basic rights of citizens. Indirect influence model service speed strategy in fulfilling the basic rights of citizens through public services.

Based on the formulation of the problem that has been observed and review the theories contained in this research then the conceptual model is obtained so the hypothesis in this study can be formulated as follows:

1. Speed strategies have a positive and significant influence on fulfilling the basic rights of citizens in rural areas.

2. The speed strategy has a positive and significant influence on fulfilling the basic rights of citizens through public administration services in rural areas.

\section{METHODS}

This research was conducted using survey design and use research methods in quantitative form. The target population is the villagers located in several districts in Jambi Province that is Tanjung Jabung Barat, Batanghari, Muara Jambi and Sarolangun, 
the reasons for choosing the four districts as a target population because the four districts are districts with the largest population growth rate in Jambi Province.

Total samples was taken based on simple random sampling technique by using Slovin formula with a confidence level of $90 \%$ so that a sample of 100 people was obtained.

The data used to test the hypothesis is primary data generated from structured questionnaires which is the instrument of this research. Operational variables are consists of variables contained in the research hypothesis. Tests carried out in this study using data analysis tools that is Partial Least Square (PLS) using smart-PLS software. Operationalization of variables can be seen in detail in Table 1.

Table 1. Operational variables

\begin{tabular}{|c|c|c|c|}
\hline Variable & Dimension & Scale & No Item \\
\hline Speed Strategy (SK) & $\begin{array}{l}\text { 1. Self-esteem } \\
\text { 2. Meet expectations } \\
\text { 3. Revamping and rediscovering } \\
\quad \text { various things } \\
\text { 4. Outlook } \\
\text { 5. Continuous improvement } \\
\text { 6. Attention } \\
\text { 7. Empowerment }\end{array}$ & Ordinals & $1-7$ \\
\hline $\begin{array}{l}\text { Public Administration } \\
\text { Services (AP) }\end{array}$ & $\begin{array}{l}\text { 1. Transparency } \\
\text { 2. Accountability } \\
\text { 3. Conditional } \\
\text { 4. Participatory } \\
\text { 5. Equal rights } \\
\text { 6. Balance of rights and obligations }\end{array}$ & Ordinals & $1-6$ \\
\hline $\begin{array}{l}\text { Fulfillment of Basic } \\
\text { Citizens' Rights (HD) }\end{array}$ & $\begin{array}{l}\text { Basic rights of citizens in public } \\
\text { services }\end{array}$ & Ordinals & $1-9$ \\
\hline
\end{tabular}

Structural equations formulated to state causality relationships between various constructs. Structural equations are:

$$
\begin{aligned}
& \mathrm{HD}=\beta 1 \mathrm{SK}+\mathrm{e} 1 \\
& \mathrm{HD}=\beta 2 \mathrm{SK} \text { AP } * \beta 3 \mathrm{AP} \mathrm{HD}+\mathrm{e} 2
\end{aligned}
$$

Furthermore, the construct contained in this study will be grouped according to the level of each construct. To find out increase in each construct it can be done in a way comparing between actual values and ideal values. Actual value is the value obtained from the calculation results the respondent's answer as a whole. While the ideal value is the value obtained from the estimated maximum or highest score multiplied by the number of questions listed on the questionnaire then multiplied again by the total number of respondents.

Score value $=\frac{\text { Actual score }}{\text { Ideal score }} \times 100 \%$

Score value can be determined according to the distribution of scores which can be seen in Table 2.

Table 2. Distribution of scores

\begin{tabular}{lccccc}
\hline Score & 1 & 2 & 3 & 4 & 5 \\
\hline Level & Very Low & Low & High enough & High & The tallest \\
Score value & $20-35.9$ & $36-51.9$ & $52-67.9$ & $68-83.9$ & $84-100$ \\
\hline
\end{tabular}


Based on Table 2, can be seen that number 1 is the minimum value or the lowest value from the scores contained in the questionnaire with score values at intervals or range 20 - 35.9. Furthermore, it is known that number 2 is included in the low category from the scores contained in the questionnaire with score scores at intervals or ranges 36 - 51.9. Then number 3 is in a fairly high category from the scores contained in the questionnaire with score scores in intervals 52 - 67.9. Number 4 is in the high category from the scores contained in the questionnaire with score scores at intervals or ranges $68-83.9$ and number 5 is the maximum value or the highest value of the scores found in the pastry with a score score in the interval 84-100.

\section{RESULT AND DISCUSSION}

\section{Result} Table 3.

Description of the speed strategy variable has been implemented as presented in

Table 3. Description of speed strategy variable

\begin{tabular}{lccccc}
\hline Sub Variable & Item & $\begin{array}{c}\text { Actual } \\
\text { Score }\end{array}$ & $\begin{array}{c}\text { Max. } \\
\text { Score }\end{array}$ & $(\%)$ & Information \\
\hline Self-esteem & SK1 & 393 & 500 & 78.6 & High \\
Meet expectations & SK2 & 386 & 500 & 77.2 & High \\
Revamping and rediscovering various things & SK3 & 389 & 500 & 77.8 & High \\
Outlook & SK4 & 402 & 500 & 80.4 & High \\
Continuous improvement & SK5 & 408 & 500 & 81.6 & High \\
Attention & SK6 & 403 & 500 & 80.6 & High \\
Empowerment & SK7 & 399 & 500 & 79.8 & High \\
\hline Average value speed strategy & & & & 79.4 & High \\
\hline
\end{tabular}

All items of speed strategy variable have been implemented in a high way. The comprehensive service speed strategy implemented in rural areas consists of; 1) selfesteem is the service officer or official in accordance with the skills and expertise possessed, 2) meet the expectations of the officer making service standard adjustments with the times and adapt them to the expectations of society, 3) revamping and rediscovery of various things is service officers receive all complaints from the public regarding the services provided, then analyze the complaint and improve the service to be implemented, 4) foresight is a public service officer utilizing technology so that work becomes more effective and efficient, 5) continuous improvement is service personnel create a good work environment and implement the best service in meeting the needs of the community, 6) attentive is a service officer providing services that are able to provide satisfaction to the community and 7) empowerment, that is, the government provides training, education, and appreciation to service officers so that they can better serve the community.

Description of variable public administration services has been implemented as presented in Table 4.

Table 4. Description of public administration services variable

\begin{tabular}{lccccc}
\hline \multirow{2}{*}{ Sub Variable } & Item & $\begin{array}{c}\text { Actual } \\
\text { Score }\end{array}$ & $\begin{array}{c}\text { Max. } \\
\text { Score }\end{array}$ & \multirow{2}{*}{$\%)$} & Information \\
\hline Transparency & AP1 & 398 & 500 & 79.6 & High \\
Accountability & AP2 & 397 & 500 & 79.4 & High \\
Conditional & AP3 & 385 & 500 & 77.0 & High \\
Participation High & AP4 & 375 & 500 & 75.0 & High \\
Similarity of Rights & AP5 & 395 & 500 & 79.0 & High \\
Balance of Rights and Obligations & AP6 & 400 & 500 & 80.0 & High \\
\hline Average value of public administration services & & & 78.3 & High \\
\hline
\end{tabular}


All items of public administration services have been implemented in a high way. Comprehensive public administration services implemented in rural areas consist of: 1). Transparency is services provided to the community is open and can be known by the general public. 2). Accountability is the service provided can be accounted for in accordance with the provisions of the applicable laws and regulations. 3). Conditional is a service provided in accordance with the capacity owned based on the principle of effectiveness and efficiency. 4). Participatory is the service provided focused on having the aspirations conveyed, the needs and expectations of the community. 5). Equality of rights where the people who enjoy the service will get the same treatment without exception. 6). Balance of rights and obligations is service always puts justice first.

The description of the variable fulfillment of basic rights of citizens has been implemented as presented in Table 5. The comprehensively basic rights of citizens in public services implemented in rural areas the overall basic rights of citizens in public services has been implemented. The community oversees the implementation of service standards, gets a response to the complaint filed, protection, and fulfillment of services. The community notifies the office leader to improve service to the community if the service provided is not in accordance with the standard of service. The community notifies service personnel to improve service if the service provided is not in accordance with the standard of service, complained about the implementers who committed irregularities service standards that do not improve service to organizers. The community complained about the service office to people who make service standard deviations and does not improve service to the community. The community gets quality services according to the government's goals.

Table 5. Description of fulfillment of basic rights of citizens variable

\begin{tabular}{lccccc}
\hline Sub Variable & Item & $\begin{array}{c}\text { Actual } \\
\text { Score }\end{array}$ & $\begin{array}{c}\text { Max. } \\
\text { Score }\end{array}$ & $(\%)$ & Information \\
\hline & HD1 & 375 & 500 & 78.0 & High \\
& HD2 & 366 & 500 & 73.2 & High \\
& HD3 & 395 & 500 & 79.0 & High \\
& HD4 & 407 & 500 & 81.4 & High \\
Basic rights of citizens in public services & HD5 & 396 & 500 & 79.2 & High \\
& HD6 & 400 & 500 & 80.0 & High \\
& HD7 & 385 & 500 & 77.0 & High \\
& HD8 & 374 & 500 & 74.8 & High \\
& HD9 & 405 & 500 & 81.0 & High \\
\hline The average value of fulfilling the basic rights of citizens & & 77.8 & High \\
\hline
\end{tabular}

The outer loading value in each statement on the speed strategy construct, construct of public administration services, and the construction of fulfilling the basic rights of citizens categorized as valid because it is above the value of 0.50 (Table 6).

Table 6. Outer loading

\begin{tabular}{cc|cc|cc}
\hline \multicolumn{2}{c|}{$\begin{array}{c}\text { Public Administration } \\
\text { Services (AP) }\end{array}$} & \multicolumn{2}{c|}{$\begin{array}{c}\text { Fulfillment of Basic Citizens' } \\
\text { Rights (HD) }\end{array}$} & \multicolumn{2}{c}{ Speed Strategy (SK) } \\
\hline AP1 & 0.741 & HD1 & 0.819 & SK1 & 0.828 \\
AP2 & 0.858 & HD2 & 0.754 & SK2 & 0.877 \\
AP3 & 0.827 & HD3 & 0.833 & SK3 & 0.814 \\
AP4 & 0.880 & HD4 & 0.846 & SK4 & 0.831 \\
AP5 & 0.895 & HD5 & 0.797 & SK5 & 0.830 \\
AP6 & 0.846 & HD6 & 0.790 & SK6 & 0.836 \\
& & HD7 & 0.788 & SK7 & 0.706 \\
& & HD8 & 0.655 & & \\
\hline
\end{tabular}


Next to find out if there are still problems related to measurement then it can be tested for unidimensionality. Test for unidimensionality is a test done to measure indicators on composite reliability and cronbach's alpha. The function of composite reliability is to measure the value of reliability on each indicator which is included in a construct. Constructions are said to meet the criteria if composite reliability has a value that is composite reliability $>7$ (Table 7 )

Table 7. Composite reliability and Cronbach's Alpha

\begin{tabular}{lcc}
\hline & Composite Reliability & Cronbach's Alpha \\
\hline Public Administration Services (AP) & 0.936 & 0.918 \\
Fulfillment of Basic Rights of Citizens (HD) & 0.931 & 0.917 \\
Speed Strategy (SK) & 0.934 & 0.917 \\
\hline
\end{tabular}

Based on Table 7, it can be seen that composite reliability to construct service strategies, construct of public administration services, and the construction of fulfilling the basic rights of citizens get a value above 0.7 , therefore it can be categorized as fulfilling the requirements. In addition, the resulting value also affects the cronbach's alpha value.

Based on Table 7, it can be seen that the value of cronbach's alpha to construct speed strategies, construct of public administration services, and fulfillment of basic rights of citizens is at a value that is above 0.6 so the measurements taken are categorized as reliable.

Path coefficient value obtained from the results of tests conducted on the model. The model was tested using sequential equation modeling through the smart 3.0 PLS program. The value of the path coefficient obtained shown in Figure 2.

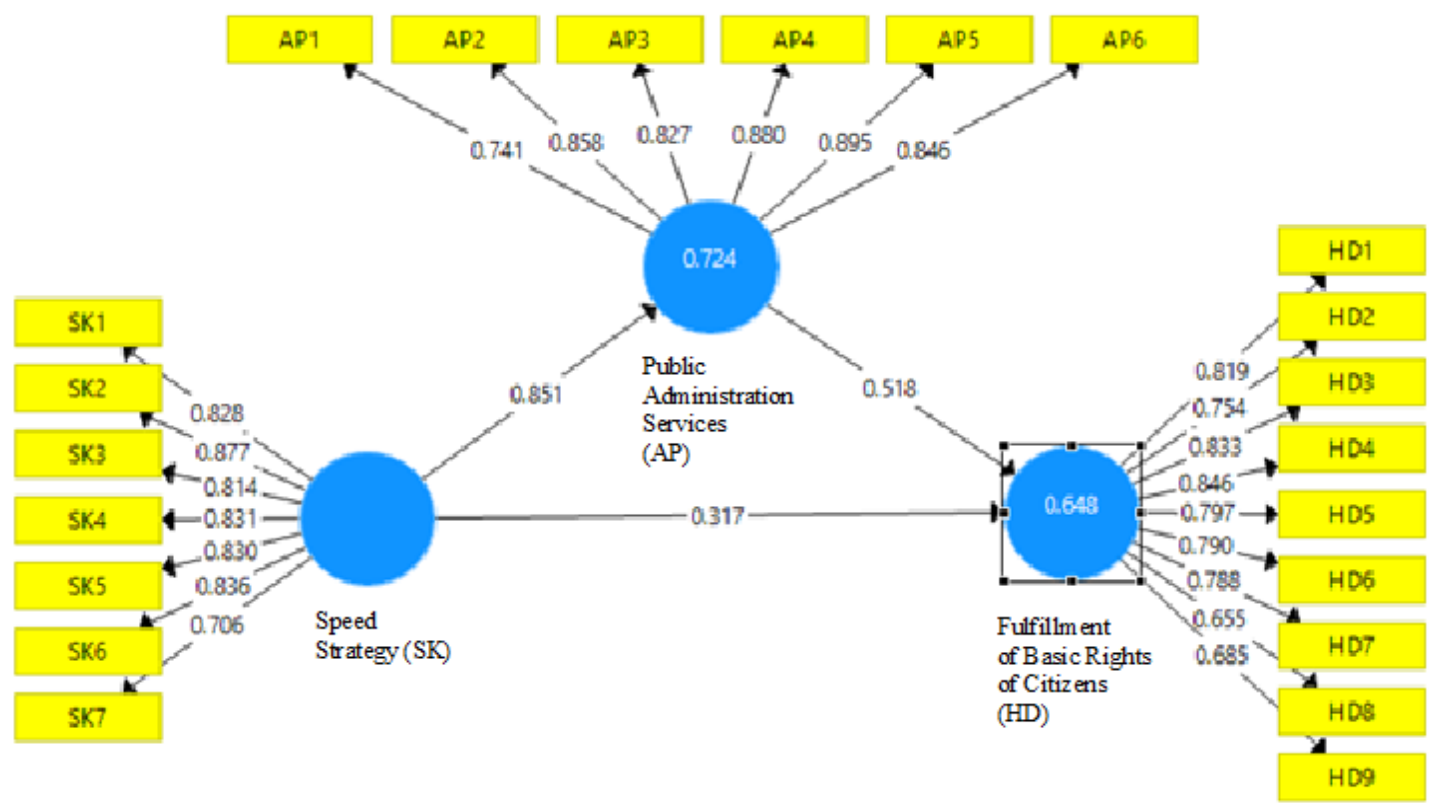

Figure 2. Path coefficients for speed strategies, public administration services, and fulfillment of basic rights of citizens

Research Model $1 \mathrm{HD}=0.317 \mathrm{SK}+\mathrm{e} 1$

Parameter coefficient value obtained for construct speed strategy (SK) towards the construct of fulfilling the basic rights of citizens (HD) that is equal to 0.317 so that it can 
be stated that speed strategy is able to have a positive influence towards fulfilling the basic rights of citizens that can be known from responsiveness provided by service personnel in response to all community needs and it can be said that fulfillment of basic rights of citizens will increase with the speed strategy.

Research Model $2 \mathrm{HD}=0.851 \mathrm{SK}$ AP $* 0.518 \mathrm{AP} \mathrm{HD}+\mathrm{e} 2$

Parameter coefficient value obtained for construct speed strategy (SK) towards the construct of fulfilling the basic rights of citizens (HD) through public administration services (AP) can be known based on the parameter coefficient value to construct speed strategy (SK) towards public administration services (AP) that is equal to 0.851 and parameter coefficient values for the construction of public administration services (AP) towards fulfilling the basic rights of citizens (HD) amounting to 0.518 . The results of data processing using PLS regarding the construct of speed strategy (SK) towards the construct of fulfilling the basic rights of citizens (HD) through the construct of public administration services (AP) by showing an indirect effect that is equal to 0.441 . These results indicate that the parameter coefficient value between the speed strategy (SK) of the construct of fulfilling the basic rights of citizens (HD) through public administration services can be interpreted that speed strategy (SK) applied by the organization has positive benefits for the fulfillment of basic rights of citizens (HD) which is implemented through public administration services (AP).

Hypothesis testing is done statistically can be known by looking at the output parameter values of the hypothesis test which corresponds to the table of total influence which can be seen in Table 8 .

Table 8. Total influence

\begin{tabular}{lccccc}
\hline & $\begin{array}{c}\text { Original } \\
\text { Sample }(\mathrm{O})\end{array}$ & $\begin{array}{c}\text { Sample } \\
\text { Mean (M) }\end{array}$ & $\begin{array}{c}\text { Standard } \\
\text { Deviation } \\
(\text { STDEV })\end{array}$ & $\begin{array}{c}\text { T Statistics } \\
(|\mathrm{O} / \mathrm{STDEV}|)\end{array}$ & $\begin{array}{c}\mathrm{P} \\
\text { Values }\end{array}$ \\
\hline AP -> HD & 0.518 & 0.515 & 0.112 & 4.640 & 0.000 \\
SK -> AP & 0.851 & 0.848 & 0.037 & 22.922 & 0.000 \\
SK -> HD & 0.757 & 0.754 & 0.068 & 11.173 & 0.000 \\
\hline
\end{tabular}

Hypothesis 1: Speed strategy has a positive and significant effect towards fulfilling the basic rights of citizens in rural areas.

The hypothesis which states that the speed strategy has a positive and significant effect on the fulfilment of the basic rights of citizens in rural areas has strong support (hypothesis is acceptable). These results are in accordance with the initial prediction (hypothesis), the speed strategy of officers in providing services is in accordance with service standards and implementing services that best meet the needs of the community so that the basic rights of citizens in rural areas are getting better.

Hypothesis 2: The speed strategy has a positive and significant influence on fulfilling the basic rights of citizens through public administration services in rural areas.

The hypothesis which states that the Speed Strategy has a positive and significant influence in fulfilling the basic rights of citizens through public administration services in rural areas has strong support (hypothesis is acceptable). This result is in accordance with the initial prediction (hypothesis), public administration services with the main goal of satisfying citizens can be a mediator between speed strategies which is a means in fulfilling the basic rights of citizens.

\section{Discussion}

This research shows that the speed strategy is able to have a positive influence on the fulfillment of the basic rights of citizens which can be seen from the responsive 
attitude given by service officers in responding to all community needs. Fulfillment of basic rights of citizens will increase with the speed strategy. The service speed strategy has been implemented in rural areas.

The speed strategy in carrying out public services fulfills the basic rights of citizens in rural areas. The community already knows the contents of the truth of service standards and oversees the implementation of service standards. In the complaints submitted, the public received a satisfying response and protection. If the services provided are not in accordance with service standards, the community notifies the service officer to improve services and the public can complain the implementer who deviated service standards to the organizer.

Communities can complain about service offices that deviate service standards and do not improve services to the community. The speed strategy of public administration services in fulfilling the basic rights of citizens in rural areas shows that public administration services in the countryside are transparent, accountable, conditional, participatory, equality of rights and obligations so the services provided to the community is open and can be accounted for in accordance with the provisions of the legislation in force. Owned capacity is guided by the principles of effectiveness and efficiency, focus on the aspirations conveyed. The community enjoys services and gets the same treatment without exception. The services provided prioritize justice.

This research is in line with the research conducted by Angkat, Kadir, \& Isnaini (2017) and Saputra, Afifuddin \& Widodo (2019) which shows that public administration services have been carried out properly in accordance with applicable requirements and procedures, service officers handle community complaints and the community feels comfortable when handling administrative files.

\section{CONCLUSIONS AND RECOMMENDATIONS}

\section{Conlucsions}

1. Speed strategy with fulfilling the basic rights of citizens in rural areas.

The speed strategy has a positive and significant influence on fulfilling the basic rights of citizens in rural areas or in other words fulfillment of basic rights of citizens in rural areas can be improved through a strategy of speed of public service.

2. The speed strategy of public administration services in fulfilling the basic rights of citizens in rural areas.

Speed strategy has a positive and significant effect towards fulfilling the basic rights of citizens through public administration services in rural areas or in other words public administration services is a mediation between the speed strategy and the fulfillment of the basic rights of citizens in rural areas.

\section{Recommendations}

1. The speed strategy in fulfilling the basic rights of citizens is in accordance with the service standards set by the government but it would be better if in fulfilling the basic rights of citizens through public administration services which can directly show the satisfaction of citizens in obtaining these services.

2. Research the strategy of the speed of public administration services in fulfilling the basic rights of citizens in rural areas still leaves potential results for further study where in this study the speed strategy has a greater influence if mediated by public administration services in rural areas rather than a direct relationship to the fulfillment of the basic rights of citizens. So for future research it is recommended to be able to focus on public administration services in fulfilling the basic rights of citizens. 


\section{REFERENCES}

Angkat, K.M., Kadir, A \& Isnaini. (2017). Analisis Pelayanan Administrasi Kependuduan pada Dinas Kepedudukan dan Pencatatan Sipil Kabupaten Dairi. Jurnal Administrasi Publik, 7 (1): 33 - 48.

Bala, A. (2017). Role of Public Administration in Good Governance and Local Development. International Journal of Economics, Commerce and Management, United Kingdom, V(5), 593 - 601

Brinkerhoff, D.W., Wetterberg, A. \& Wibbels, E. (2017). Distance, services, and citizen perceptions of the state in rural Africa. Governance, 31, $103-124$

Chatzoglou, P., Chatzoudes, D., Vraimaki, E., \& Diamantidis, A. (2013). Service quality in the public sector: the case of the Citizen's Service Centers (CSCs) of Greece. International Journal of Productivity and Performance Management, 62(6), 583605. doi:10.1108/ijppm-12-2012-0140

David, F.R. (2011). Strategic Management: Concept and Cases. Edition 13th. USA: Pearson Education.

Fadillah, A. \& Sujianto. (2018). Strategi Meningkatkan Kepatuhan Standar Pelayanan Publik (Studi Kasus Dinas Penanaman Modal \& Pelayanan Terpadu Satu Pintu Provinsi Riau). JOM FISIP, 5 (1): 1 -12.

Hardiyansyah. (2011). Kualitas Pelayanan Publik: Konsep, Dimensi, Indikator, dan Implementasinya. Yogyakarta: Gava Media.

Ibrahim. (2008). Teori dan Konsep Pelayanan Publik Serta Implementasinya. Jakarta: Maju Mundur.

Jairo, A.A., Nguyen, C., Tran, A. \& Phung, T. (2015). The urban-rural gap in governance and public administration: evidence from Vietnam. International Public Management Review, 16(1), 165 - 191

Kerlinováa, A. \& Tomášková, E. (2014). Approach to strategy at public administration organizations in the Czech Republic. Procedia - Social and Behavioral Sciences, 156, 88 - 92. doi: 10.1016/j.sbspro.2014.11.125

Mosso, A., Singkoh, F. \& Sumampow, I. (2018). Kualitas Pelayanan Administrasi Kependudukan di Dinas Kependudukan dan Catatan Sipil Kabupaten Maybrat Provinsi Papua Barat. Jurnal Jurusan Ilmu Pemerintahan, 1(1), 1 - 12.

Munhurrun, P.R., Bhiwajee, S.D.L \& Naidoo, P. (2010). Service Quality in The Public Service. International Journal of Management and Marketing Research, 3(1), 37 50.

Pasolong, H. (2014). Teori Administrasi Publik. Bandung: Alfabeta.

Rangkuti, F. (2013). Analisis SWOT: Teknik Membedah Kasus Bisnis. Jakarta: PT. Gramedia Pustaka Utama.

Rukayat, Y. (2017). Kualitas Pelayanan Publik Bidang Administrasi Kependudukan di Kecamatan Pasir Jambu. Jurnal Ilmiah Magister Ilmu Administrasi (JIMIA), 11(2), $56-65$.

Saputra, S.D., Afifuddin \& Widodo, R. (2019). Kualitas Pelayanan Publik Bidang Administrasi Kependudukan di kecamatan Kepanjen Kidul. Jurnal Respon Publik, $13(2), 38-44$.

Sinambela, L. (2012). Reformasi Pelayanan Publik: Teori, kebijakan, dan implementasi. Jakarta: Bumi Aksara.

UNDP. (2015). From Old Public Administration to the New Public Service Implications for Public Sector Reform in Developing Countries. UNDP Global Centre for Public Service Excellence, Singapore. 